\title{
AS RELAÇÕES INTERÉTNICAS: OS TERENA E OS DEMAIS ATORES SOCIAIS EM MATO GROSSO DO SUL
}

\author{
Noêmia dos Santos Pereira Moura ${ }^{1}$ \\ Rosalvo Ivarra Ortiz ${ }^{2}$
}

\begin{abstract}
Resumo: Neste artigo apresentamos as relações interétnicas entre os Terena e os atores sociais com os quais estreitaram os contatos ao longo do século XX. Em algumas passagens do texto sentimos a necessidade de realizar algumas digressões para situar o leitor acerca das permanências ou rupturas históricas. Dessa forma, realçamos, principalmente, as relações entre os indígenas e o Estado brasileiro. Portanto, percorremos rapidamente as últimas décadas do século XIX e entranhamo-nos no XX.
\end{abstract}

Palavras-chave: Terena, Contatos, Atores.

\section{INTERENGTHIC RELATIONS: THE TERENA AND THE OTHER SOCIAL ACTORS IN MATO GROSSO DO SUL}

\begin{abstract}
In this article we present the interethnic relations between the Terena and the social actors with whom they narrowed contacts during the twentieth century. In some passages of the text we feel the need to make some digressions to situate the reader about the permanences or historical ruptures. In this way, we highlight, mainly, the relations between the natives and the Brazilian State. So we went through the last decades of the XIX th century and got into the $\mathrm{XX}$ th.
\end{abstract}

Keywords: Terena, Contacts, Actors.

\section{LAS RELACIONES INTERÉTNICAS: LOS TERENA Y LOS DEMÁS ACTORES SOCIALES EN MATO GROSSO DEL SUR.}

Resumen: En este artículo presentamos las relaciones interétnicas entre los Terena y los actores sociales con los que estrecharon los contactos a lo largo del siglo XX. En algunas pasajes del texto sentimos la necesidad de realizar digresiones para situar al lector acerca de las permanencias o rupturas históricas. De esa forma, realzamos principalmente, las relaciones entre los indígenas y el Estado brasileño. Por lo tanto, recorrimos rápidamente las últimas décadas del siglo XIX y entró en el XX.

Palabras clave: Terena, Contactos, Actores.

\footnotetext{
${ }^{1}$ Doutora em Ciências Sociais pela Universidade Estadual de Campinas - UNICAMP. Docente da Universidade Federal da Grande Dourados (UFGD), no Curso de Ciências Sociais e no Programa de Mestrado em Antropologia da UFGD.

${ }^{2}$ Mestrando em Antropologia Sociocultural pela Universidade Federal da Grande Dourados (UFGD). Bolsista da FUNDECT/MS.
} 


\section{INTRODUÇÃO}

No início da República, um dos objetivos do governo brasileiro era interligar as diversas regiões do Brasil. Nesse intuito lançou os projetos da Comissão de Linhas Telegráficas (1889- 1904) e da Estrada de Ferro Noroeste do Brasil (1904-1914). A primeira acelerou as comunicações e a segunda facilitou o fluxo de pessoas e produtos, que repercutiu por aquela parte do território brasileiro. No Estado de Mato Grosso, essas ações foram completadas nas primeiras décadas do século XX. Todavia, tais empreendimentos ocuparam lugar no pensamento de seus gestores logo após o desfecho da Guerra contra o Paraguai em 1870. É perpendicular a essas empreitadas que se dá outra, não menos importante: as terras reservadas. Dizemos perpendicular, porque foi profundamente atravessada pelas duas primeiras, principalmente pela segunda, a Estrada de Ferro Noroeste do Brasil (NOB). Em Aquidauana -MS, as aldeias Bananal e Ipegue ficam próximas à estação da NOB, cuja sede se encontra no Distrito de Taunay.

Em seu estudo, a pesquisadora Vera Lúcia Vargas (2003), procurou demonstrar, como o processo de lutas do povo Terena para recuperar suas aldeias junto ao governo imperial brasileiro, após a Guerra contra o Paraguai. Ficaram evidenciadas pela autora as diversas ações empreendidas pelas lideranças indígenas na reconquista de suas antigas aldeias existentes antes da deflagração daquele conflito platino. A tarefa não foi das mais fáceis para esse povo, como ficou exposto no Officio dirigido ao Governo Imperial pelo Presidente da sobredita província o Exm. Sr.coronel Ricardo José Gomes Jardim, que está presente na obra de Vasconcelos (1999):

[...] nenhuma aldêa propriamente dita existe actualmente n'esta província, achando-se há muitos annos extincta a aldêa de índios Bororós, estabelecida em 1761, no termo d'esta cidade, pelo capitão general conde d'Azambuja, e fundidos os seus descendentes na massa da população (Apud VASCONCELOS, 1999, p. 139).

Pelo trecho do Officio acima transcrito percebemos que o governo imperial só reconhecia como aldeias os espaços por ele geograficamente constituídos, o que vai se tornar evidente quando iniciarem as reivindicações dos Terena após a referida Guerra. Várias expedições organizadas por lideranças Terena foram realizadas à sede do Governo da Província. Todavia, dadas as ações Terena e a necessidade de organizar as relações nas áreas 
de fronteiras, o governo estabelecerá como meta demarcar o "lugar do índio no território brasileiro" e, principalmente, no Sul de Mato Grosso de onde vinham as insistentes demandas dos Terena (VARGAS, 2003).

O Estado brasileiro, em seu percurso rumo à modernização, pretendendo secularizar todas as atividades civis e militares, proclamou a liberdade religiosa na Constituição de 1890. $\mathrm{Na}$ implantação dessa política firmou convênios assistenciais com algumas Missões Protestantes. A política indigenista republicana nascia, portanto, com um novo caráter. Seria gestada no âmbito de um Estado Nacional formalmente separado das ordens eclesiásticas católicas. Criava-se, para tanto, o Serviço de Proteção ao Índio (SPI) vinculado ao Ministério da Agricultura, cujo objetivo central era "gerir a relação entre os povos indígenas, distintos grupos e demais aparelhos do poder" (LIMA, 1995, p. 155). Segundo Lima, destarte os discursos dos intelectuais que registraram o nascimento desse órgão como resultado de um debate público, sua criação estava prevista pelo Ministério da Agricultura, Indústria e Comércio (MAIC), desde 1906. O pressuposto era, segundo o pensamento positivista, de que o SPI através de ações governamentais protegeria aos índios e promoveria sua integração à população brasileira.

Os Terena, cujas relações sempre foram abertas às negociações, foram eleitos pelo Estado como uma das etnias que mais se aproximava do índio idealizado do processo de integração do índio à sociedade nacional. Dessa estreita relação com o governo brasileiro, os Terena assumiram a identidade de civilizado. O estandarte de civilizados e civilizadores é ainda hasteado pelas lideranças missionárias Terena na atualidade, quando se referem às etnias em processo de evangelização. Os missionários indígenas da Missão Indígena UNIEDAS (MIU) pensam-se como verdadeiros escolhidos de Deus. Acreditam que o Evangelho veio aos Terena, porque foram selecionados por Deus para levá-lo aos demais povos indígenas. Essa é a Missão - "civilizar outros povos indígenas tal como fomos civilizados", disse-nos uma dessas lideranças. Enfatizam que a mensagem transmitida de indígenas para indígenas se torna mais fluente e melhor compreendida (MOURA, 2001). Entretanto, não são somente os evangélicos que têm essa postura.

Os demais anciãos ressaltam a honra e o prestígio dos líderes Terena ancestrais. $\mathrm{Na}$ História de Oncinha quando foi ao Chaco, cuja autoria é dada a Apolinário Lili (Áxavara), um dos troncos velhos Terena da aldeia Bananal, o ancião nos fala do prestígio de seu Chefe - o 
Capitão Tavares. Foi a esse Capitão que Rondon teria se reportado em suas memórias sobre a demarcação das terras de Ipegue em 1905. O relato do ancião indígena segue assim:

Antigamente havia um Terena, patrício nosso, que se chamava Oncinha. Ele tinha um amigo chamado Tavares, Capitão Tavares. Esse homem era chefe do povo Terena. Esse Oncinha foi ao Chaco. Mas antes disso, o Capitão Tavares foi ao Rio para falar com o rei, e Oncinha foi com ele, pois era seu amigo. No tempo de Oncinha, o rei do Brasil governava no Rio de Janeiro. Nesse tempo o chefe do Brasil era conhecido como rei, mas agora em nossos dias é conhecido como presidente, e não mais como rei. (...) Quando Tavares e Oncinha chegaram ao Rio, o rei tratou-os muito bem e os honrou dandolhes boas vindas. O rei lhes deu roupas e vestiu Tavares com roupa própria de um chefe. Dizem também que havia muitos músicos que foram mandados pelo rei ao encontro deles para tocar em sua homenagem. O rei os tratou como pessoas importantes. Oncinha não saía de perto do seu amigo, ficava sempre com ele. Na volta dessa viagem ao Rio somente Oncinha chegou, o Capitão Tavares não. Suspeita-se que ao chegarem em São Paulo, Tavares tenha sido envenenado. Dizem que os brancos o 105 envenenaram, talvez por inveja pela maneira como o rei o tinha honrado, pois em geral os brancos não querem o nosso bem. [...] Quando Tavares, o verdadeiro chefe dos Terena morreu, Oncinha o substituiu (Vúkeaku, uti têrenoe, 1997, p. 10-11).

Podemos perceber, através do relato acima, que a seu modo os Terena datam os acontecimentos históricos vividos pelo seu povo. Geralmente, se reportam aos ciclos de lideranças políticas no poder. Por exemplo, para datar o início da escolha dos caciques através do voto, procura-se lembrar de qual fora o último Cacique escolhido pela tradição.

Dá bem para perceber, no trecho destacado, que o Senhor Apolinário relata um fato ocorrido ainda no Brasil Império e que naquela época as lideranças Terena deslocavam-se até a Capital do Império para reivindicar de Chefe para Chefe. É perceptível também, na minúcia do relato, que o Imperador deu ao Chefe dos Terena o tratamento digno de um Chefe de Nação. Suas vestes, a música, o banquete e as honras são somente oferecidos a personalidades importantes. "O rei os tratou como pessoas importantes". É assim que os Terena esperam continuar sendo tratados, como pessoas destacadas e, para isso, afirmam-se em sua conduta e etiqueta. Os códigos da civilidade que os conduziu ao Rio de Janeiro continua a acompanhálos nos dias atuais quando se deslocam à Aquidauana, Campo Grande e a Brasília. São os Chefes de um Povo em diálogo com outros Chefes.

Os Terena estão na margem oriental do Rio Paraguai desde meados do século XVIII, desenvolvendo respostas e adaptações criativas às situações de contatos desenvolvidos com outras etnias indígenas e não indígenas (SCHUCK, 1995; SILVA, 2001; AÇÇOLINI; 
SANT'ANA, 2004; CARVALHO, 1996; MOURA, 2001; MUSSI, 2000; VARGAS, 2003). São descendentes diretos dos Chané/Guaná que habitavam a região do Chaco antes do processo de colonização Ibérica das Américas do Sul e Central. Desenvolveram sua territorialidade no espaço conhecido, historiograficamente, como sul da Província de Mato Grosso ou Districto do Baixo Paraguay (COSTA, 1999). Solicitaram proteção ao comando do Prezídio de Miranda contra as usurpações dos Guaikurú, com os quais conjuntamente fugiram dos colonizadores espanhóis. O Presídio, construído pelas forças portuguesas em 1776, significava para os Guanás, naquele momento, uma nova fonte de poder em pé de igualdade com os índios cavaleiros, seus vizinhos e tributários. Segundo um relato de Caldas de 1887, desde o ano de 1796 estabeleceram-se ali grandes malocas de índios Guaicuru e Guaná (CALDAS, 1887, p. 132). Malocas é um termo pejorativo utilizado pelos colonizadores para aqueles agrupamentos indígenas que entendiam viverem em estado selvagem.

As etnias das famílias Guaikuru e Guaná formaram suas aldeias e se reproduziram física e culturalmente em contato com as forças lusas e os primeiros fazendeiros que se fixaram na primeira metade do século XVIII (OLIVEIRA, 1968; LEITE, 2003). Mesmo com a presença militar portuguesa, os Guaikurú continuavam sendo soberbos, como bem observara Ricardo Franco em 1845 em relação aos Guaná.

A soberba e rivalidade dos uaicurús é tal, que se infunde nos mesmos guanás logo que passam a viver, ou nascem entre os altivos uaicurús, tratando os outros com desprezo, e publica superioridade, mormente até o anno de 1799, chegando alguns capitães uaicurús, e ainda aquelles mesmos, cujas mães e mulheres sempre foram guanás, como os capitães Paulo, e Luiz Pinto, a fazer levantar da minha mesa, e a comer sentados no chão, a algum capitão guaná que viam n'ella, e a dizerem-me que, se eu comia, elles o não faziam com seus captiveiros. (...)

[...] Porém, vendo os uaicurús que no dito anno foram dois guanás á VillaBella fallar a V. Ex., e o capitão Ayres Pinto e outro guaná a Villa Maria, para onde presumiam se queriam mudar os guanás, desde essa época mudaram os uaicurús de modos e estylos, chamando aos guanás de amigos e parentes, convidando-os para suas festas, e mesmo para minha mesa, temendo essa mudança; porque n'ella perdiam mulheres, parte de seu sustento e das suas forças, pelos convidarem sempre para as suas expedições bellicas; com o que, e com esse novo e mais igual modo de tratamento se tem conformado mais os guanás com os seus antigos e ainda actuaes oppressores, que de vez em quando lhes não deixam de fazer suas violências, e de os chamar sempre seus captiveiros (SERRA, 1845, p. 132-33). 
Como anunciado no início do artigo faremos uma rápida digressão para situar algumas práticas Terena. O deslocamento do Chaco foi uma das formas encontradas pelos povos indígenas migrantes para negarem a colonização. Não obstante, a outra margem do Rio Paraguai também estava sendo disputada por espanhóis e portugueses. O Tratado assinado em 1791, pelos Guaikuru com a Coroa Portuguesa, o qual teve a participação Guaná, simbolizou a compreensão desses últimos da disputa corrente. Era necessário, naquele momento, unir-se aos portugueses contra os seus perseguidores espanhóis do Chaco. Dessa forma, os Guaná/ Chané também o fizeram. Selaram a paz com os militares do Prezidio de Miranda, fornecendo-lhes gêneros alimentícios e produtos artesanais. Todavia, rejeitaram enquanto puderam as reduções. Pouco antes da Guerra contra o Paraguai (1864-70) suas relações com os não índios limitavam-se às trocas comerciais.

Até a Independência do Brasil, a política de ocupação da Coroa Portuguesa de todas as terras da Colônia seguia irreversivelmente. O estado de guerra contra os índios bravos era constante. Novas propostas surgiram somente após 1822, quando o Império percebeu que os indígenas constituíam-se em fronteiras vivas contra as invasões de outras nações (VASCONCELOS, 1999). O autor afirmou que o tratamento dispensado aos indígenas dependia da recepção feita aos colonizadores. Em suas palavras,

O que caracterizou a ação política no início do governo imperial, com poucas exceções, foi o seguinte: para os índios bravos, arredios e selvagens, não-susceptíveis à pacificação, a perseguição e o castigo; para os pacificados e "amigos da civilização", a sua integração ao Estado via concessões a particulares ou a projetos encabeçados pelo próprio Estado (VASCONCELOS, 1999, p. 44).

A política indigenista, entretanto, não era geral e algumas províncias ficavam descobertas no tocante às ações governamentais. A abertura da lei facilitava a determinadas Províncias agirem de acordo com suas necessidades. Vasconcelos complementou seu raciocínio afirmando que por não ser uma diretriz global, "a política do governo central nesse período oscilava de província para província: ao mesmo tempo que dava, em algumas, 'carta branca' para a atuação das "bandeiras" contra os índios selvagens, proibia, em outras, os meios violentos" (VASCONCELOS, 1999, p. 44). O Estado Imperial tinha como meta proteger as fronteiras consolidadas a partir da independência. Portanto, seu foco centrava-se principalmente nas etnias que se situavam naquelas localidades. 
As etnias indígenas situadas no Districto do Baixo Paraguay eram alvos dessas diretrizes oscilantes. Muitas delas, no entanto, se esquivaram por muito tempo até serem concentradas pelos missionários católicos, sob a orientação estatal. Algumas faziam enfrentamento direto com outras etnias indígenas e com os regionais. A guisa de exemplo destacamos os Paiaguás, considerados índios ferozes que, segundo a visão imperial, prejudicavam o comércio regional com seus frequentes ataques. Para eles só restavam à submissão ou a eliminação (idem, p. 59;). Segundo o Diretor dos Índios da Província de Mato Grosso,

Foram classificados 3 tipos de grupos indígenas: Primeiramente os que vivem aldeados sob nossa vista; em segundo lugar os que vivendo ainda no primitivo estado de independência todavia relacionam-se conosco; e em terceiro lugar os que nos hostilizão e não se mostrão dispostos a mudarem seu modo de existência. Classificou os Guaná no primeiro grupo: (...). Guaná Terenas. Vivem aldeiados nas immediações do Prezidio de Miranda (Relatório de 2 de dezembro de 1848: 13).

Os Terena, apesar de sua presença enquanto índios semicivilizados, só vieram a compor um Aldeamento Regular no ano de 1859, como enfatizamos nas páginas anteriores, às vésperas da Guerra da Tríplice Aliança. Mesmo assim, as evidências documentais apontam que não estavam muito afeitos àquele sistema. Viviam em aldeamentos espontâneos estabelecidos na Villa de Miranda e, provavelmente, participavam de alguns rituais católicos, tal como os demais indígenas e regionais. Por conta desse comportamento amistoso, o conceito desse povo, tido como manso, era bom perante a opinião do Director Geral dos Índios, Joaquim Alves Ferreira, de acordo com seu Relatório de 1848. O Diretor relatou extensamente sobre os Guaná e suas parcialidades, as quais eram consideradas por ele como mais aptas à civilização, embora afirmassem que algumas fossem mais acessíveis que as outras. No texto citado a seguir, classificou quatro tribos entre os Guanás, salientando que dentre essas os Kinikinaos eram os indígenas mais suscetíveis à integração que os Terena. Enfatizou que os Kinikinaos aldeados "estão em estado de se curar de sua educação intellectual e religioza". Daí em diante, todos os demais interlocutores do Estado brasileiro passaram a realçar as qualidades dos Guaná: trabalhadores, amigáveis, receptivos, solidários, obedientes e integráveis. 


\section{OS GUANÁS}

As quatro tribos de que se compõem essa nação pouco ou nada differem entre si quanto ao modo de existência, seos costumes são manços pacíficos e hospitaleiros, vivem reunidos em aldeias mais ou menos populosas e muitos delles se ajustão para serviços de toda espécie em diversos pontos da Província e mormente para navegação fluvial. Sustentam-se da caça e da pesca, mas principalmente da carne de vaca e dos produtos de sua lavoura. Cultivão milho, mandioca, (da qual fazem soffrivel farinha), arroz, feijão, cana, batatas, hortaliças e igualmente todos os gêneros de agricultura do paiz. As suas colheitas não só chegam para seo consumo como que lhes resta hum excedente que vendem a dinheiro ou permutão por diversas fazendas, ferramentas aguardente, espingardas, pólvora, chumbo e quinquilharias e bem assim gado vacum e cavallar, de cuja criação ocupão-se. Fião, tecem e tingem o algodão e a lã do que fazem optimas redes, pannos, cintos e suspensórios, e quase todos entendem e fallão o nosso idioma e. (...) finalmente já estão esses índios em estado de receber com proveito o ensino moral e religioso e muito conviria que entre elles fossem residir com os Missionários...". sugere ainda o aldeamento dos Chamacocos no... "Mato Grande distante três legoas a oeste de Albuquerque e onde já existe huma grande e prospera aldeã Kinikináos" (Relatório de 2 de dezembro de 1848, p. $6)$.

No tocante ao Mato Grosso, até 1845, suas autoridades agiram de acordo com os interesses locais. O Regulamento acerca das missões de catequese, e civilização dos índios (1845) propôs a nacionalização de uma política indigenista para o Brasil. Todavia, é interessante ressaltar que as dificuldades encontradas pelas Presidências de Províncias para aplicar tal Regulamento não eram poucas. A maioria das tribus habitantes da Província classificava-se no segundo e terceiro tipos de grupos indígenas - estado primitivo e independente e não dispostos a mudarem seu modo de existência hostil e agressivo, conforme o acima descrito. Os Terena localizavam-se na liminaridade entre o primeiro e o segundo grupo. Estavam sob as vistas do Império, no entanto não aceitavam a redução religiosa. Excelente exemplo, aos olhos do Director Geral dos Índios, eram os Kinikinao aldeados na Aldeia Nossa Senhora do Bom Conselho, antes mesmo da criação do Regulamento das Missões. Todavia, sua listagem de povos indígenas que integravam o terceiro grupo - dos agressivos e selvagens - era extensa (Relatório do Director Geral dos Índios de 02 de Maio de 1863).

As aldeias espontâneas, no entanto, estavam com os seus dias contados. Fugiam completamente do padrão das aldeias reconhecidas pelo Estado e pela Igreja. Viviam sob a organização e direção dos próprios indígenas. Teriam de se adequar à situação de Aldeia 
Regular ou Secular. Essa necessidade ficaria evidente após a publicação da Lei de Terras, pela qual aldeias espontâneas serão desconsideradas enquanto Terras Indígenas e as regulares ou seculares serão recomendadas pelo Presidente da Província, em cumprimento ao Decreto Imperial de 1845, anteriormente destacado. Essa será uma das grandes batalhas dos Capitães Terena, após a Guerra contra o Paraguai: o reconhecimento das aldeias Terena enquanto espaços geográficos brasileiros.

A 28 de dezembro de 1852, segunda metade do século XIX, o Diretor Geral dos Índios - Henrique José Vieira - relatou ao Presidente da Província em Cuiabá a existência de uma aldeia Guaná no Baixo Paraguay, sendo que para os Guaná existiam outras.

Aldêa, propriamente dita, existe uma de Guanás em Albuquerque no MatoGrande, dirigida pelo digno Missionario Capuchino Frei Mariano de Banhaia, que alli fez levantar uma Capella da invocação de Nossa Senhora do Bom Conselho, para qual fiz remetter os dous sinos, que por ordem de $\mathrm{V}$. Ex. mandei vir do Rio de Janeiro. Os indios dessa aldêa são todos lavradores, as indias fião e tecem algodão, e já costurão soffivelmente, os pequenos aprendem a ler e escrever (pois alli existe um Mestre de $1^{\mathrm{a}} \mathrm{s}$ Lettras) e nessa occasião apresento a V. Exa. As escriptas dos ditos pequenaos (Relatório da Diretoria Geral dos Índios de 28/12/1852, p. 17-18).

Aldeia propriamente dita, informou o Diretor, desconsiderando as formações sociais espontâneas. Havia uma conformação específica, gerenciada e orientada pelas autoridades brasileiras, reconhecida como aldeia que diferia das organizações desenvolvidas pelos Guanás independentes. As "novas aldeias", configuradas em parceria de missionários e estadistas, representavam a indissociável relação entre o religioso e o secular contra a cosmovisão indígena. Naquela ocasião, após a publicação da Lei de Terras (1850), surge a necessidade de redefinição do que vem a ser uma aldeia, propriamente dita. Um entendimento diferente do governamental estaria fora da abrangência da Lei, como foi o caso das aldeias Terena.

Essa necessidade de definição de aldeia, oficialmente reconhecida pelo Estado brasileiro, nasce com a Lei de Terras, pois em 1848, os Guaná Terena eram reconhecidos e classificados como semi-civilizados e aldeados nas "immediações do Prezidio de Miranda". Naquele momento, década de 1840, encontravam-se próximos de se curar de sua educação intellectual e religiosa, como relatou o Diretor de Índios. Em 1852, apenas quatro anos após o relatório de reconhecimento das aldeias Guanás, a Presidência da Província registrava somente a Aldeia Bom Conselho, dos Kinikinao. A questão, segundo constatamos, é de terras. As Aldeias Regulares e Seculares, organizadas de acordo com o Regulamento das Missões, 
seriam reconhecidas pelo Império. As demais formações indígenas foram legalmente ignoradas. Aqueles Terena, que antes de 1850 eram os guardiões das fronteiras, constituíramse após a Lei de Terras em obstáculos ao progresso (VARGAS, 2003). Todavia, em 1858, João Baptista D’Oliveira, Director Geral dos Índios, em relatório circunstanciado sobre a Catequese e civilização dos índios da Província de Mato Grosso, identificou novamente os aldeamentos dos Terena e demais povos semi-civilizados. Em suas palavras,

Os indios Terena e Layanas, habitantes das immediações de Miranda, pertencem à tribu da Nação Guaná o numero dos seos individuos sobe a 2.300 segundo a synopse que já fallei, organizada pelo finado Director Joaquim Alves Ferreira.

Esses indios são mansos, pacíficos e hospitaleiros: vivem reunidos, porem sobre si, em aldeias mais ou menos populosas: cultivão a terra, e plantão o milho, feijão, arroz, cana, e outros generos do paiz.

As suas colheitas são abundantes, e não só chegão para seo consumo, como dão-lhes um excedente com que, nas vendas e permutas, supprirem aos habitantes da Villa. Occupão-se também da creação do gado vacum e cavallar: ajustam-se para todos os serviços, e principalmente para a navegação fluvial. As mulheres fião e tecem algodão, e a lã do que fazem boas redes, cintas e suspensórios. Entendem e fallão o nosso idioma (...): Já duas tentativas se fizerão para reunil-os núma só aldea regular de conta desta Directoria Geral sob a direcção de Fr. Antonio de Molinetto, mas a falta de vocação desse Missionário para catechisar, mallogrou-as.

Em janeiro do corrente anno foi nomeado o Cap. Caetano da Silva Albuquerque Director das Aldeas destes Indios, para fim de preparal-os d'antemão, para em tempo opportuno se reunirem sem dificuldade n'uma só aldêa, e receberem de bom grado a catechese (...) (Relatório de João Baptista D’Oliveira, Director Geral dos Índios, 1858, p. 92-99).

No texto imediatamente acima destacado, o relatório tratou especificamente sobre os Terena e Layana que conviviam em aldeias nos arredores da Vila de Miranda. Foram caracterizados como mansos, pacíficos e hospitaleiros pelo Diretor embora, vivessem reunidos independentemente do poder nacional constituído: Viviam sobre si. O relator enfatizou, bem como o fizeram os relatores que o antecederam, a produtividade e a comercialização como iniciativas indígenas e o relevante papel de suprimentar de mantimentos os moradores da respectiva Vila. Dessa feita, realçou as referidas etnias enquanto sujeitos ativos no processo de povoamento e desenvolvimento do sul de Mato Grosso. Entretanto, a suposta ineficiência do missionário responsável pela redução e catequização desses indígenas por duas vezes teria inviabilizado essa tarefa. 
Questionamos justamente essa "ineficiência missionária”, uma vez que a metodologia capuchinha, no sentido de ressignificar a cosmologia Terena foi amplamente eficiente com relação aos Kinikinao e Guaná. Somos mais favoráveis à hipótese da inconstância Terena, ao invés de respaldar a tese da incapacidade missionária de Frei Molinetto (VIVEIROS DE CASTRO, 2002). As condições, nas quais se relacionavam os núcleos populacionais Terena e o povoado de Miranda, eram favoráveis tanto aos indígenas quanto aos regionais, diferentemente daquelas produzidas após a Lei de Terras. Em Abril de 1860, década na qual foi criada a Aldêa Normal de Miranda, sob a direção de Frei Mariano de Bagnaia e consentimento dos indígenas, estava em vigência uma nova política indigenista.

Foi naquela mesma época que a verba da rubrica Catechese e Civilização, administrada pela Diretoria Geral dos Índios (DGI) e suas subordinadas, as Diretorias Distritais das Aldeias Regulares e Seculares, foi reduzida. Essa redução de investimentos foi premeditada, uma vez que o Estado entendia que os povos indígenas classificados como integrados podiam se auto sustentar dadas as ações econômicas que desenvolviam anteriormente com os regionais. Todavia, a ação governamental repercutiu diretamente nos trabalhos empreendidos por Frei Bagnaia, em Miranda, e por Frei Caramânico, em Bom Conselho. Ambos queixavam-se às autoridades sob o estado de miserabilidade enfrentado pelos redutos regulares e seculares, como se verá na citação abaixo destacada.

Mesmo assim, com parcas divisas segundo os relatórios consultados, Frei Mariano progrediu em suas atividades junto aos indígenas, conforme demonstram os Ofícios remetidos à Presidência pelo Director Geral de Indios. Estabeleceu a Escola de Primeiras Lettras, elevou uma Capella a São Francisco de Assis, que muitos anos demorou para vê-la concluída, e implantou uma roda de ralar mandiocas para amenizar a sofrível luta dos indígenas para fazer a farinha. Contudo, acreditamos que a Aldêa Normal de Miranda não teve tempo hábil de funcionar ao gosto e zelo de Frei Mariano de Bagnaia, dado o advento da Guerra contra o Paraguai, cujo Sul da Província de Mato Grosso fora cenário de batalhas. Em complemento, destacamos o relatório a respeito da Catechese e Civilização de 1862.

[...] passo a tratar das Aldeas estabelecidas, começando pela de Kinikinaos de N. Snr ${ }^{a}$ do Bom conselho. (...) A índole d'esses İ́ndios é a mais excellente possível, e por isso é de lamentar-se que não se possa eleval-os ao grau de civilisação à que têem direito de reclamar dos Poderes do Estado, que nisso encontrão interesse. 
As relações interétnicas: os Terena e os demais atores sociais em Mato Grosso do Sul Noêmia dos Santos Pereira Moura; Rosalvo Ivarra Ortiz

Aldea Normal de Miranda - Mandada fundar pelo Exmo. Governo Provincial em Abril de 1860, sob a direcção do incansavel Missionário frei Mariano de Bagnaia, que mui relevante serviços tem prestado á catechese do Índios d'esta Província. Acha-se porem esta aldea em embrião por ter partilhado da sorte da do Bom conselho na suspensão das suas obras e dispensa dos empregados que nella servião, por falta de numerário para acodir a essas despezas.

Grande é o numero de Índios, que para alli forão atrahidos pelo referido Missionário, e uma não pequena porção ainda resta disseminada nas visinhanças d'aquella villa, que o director empenha-se em incorporal-a na referida aldea; o que será de grande conveniência e utilidade, por ser um recurso aos agricultores da Villa de Miranda, não só por que os Índios Terenas e Laiana, que n'ella habitão prestão-se aos mesmos trabalhos dos da Aldeã do Bom Conselho como por que abastecem aquella Villa de gêneros alimentícios de suas plantações (Relatório do Director dos Índios João Baptista D'Oliveira ao Presidente da Província Conselheiro Herculano Ferreira Penna. Cuiabá, 28 de abril de 1862, p. 23-26).

Tanto os Terena como os Layana, segundo o relatório do supracitado Diretor de Índios, prestavam serviços diversos aos regionais e abasteciam a Vila de Miranda com suprimentos agrícolas. No entanto, faltava-lhes a catequese, através da qual poderiam elevarse ao grau de civilização à qual tinham direito de reclamar aos Poderes do Estado, que nisso encontram interesse, segundo enfatiza o relator. Ele mesmo observara que era de interesse dos Terena elevarem-se à civilização. Civilizados seriam reconhecidos enquanto súditos do Imperador e por conseguinte, poderiam cobrar deste seus direitos enquanto tais. Sem recursos o Diretor da Aldeia ficava impossibilitado de implementar a educação e a catequese dos indígenas. Apesar de não ficar evidente, o documento sugere que eram os Terena os autores do boicote ao trabalho fora da aldeia secular. Além do mais os Guaná tinham, de acordo com as formações espontâneas em torno dos troncos, vários Capitães. Segue um trecho do Ofício de 1861 remetido pelo Director Geral ao Presidente de Província.

Participando-me o Director dos Índios do Município da Villa de Miranda Frei Mariano de Baguaia em officio datado de 6 de Junho ultimo, que mandando na aldea vã praça de $1^{\mathrm{a}}$ linha solicitar dos Capitães 4 Indios para serem empregados no serviço da Igreja Matriz, fora o mesmo soldado à pouca distancia d'Aldea accometido por uma porção de Índios armados de facas e espingardas, que tinhão vindo apoz do soldado para tomarem os 4 indios, como effetivamente o fizerão, apresso-me em levar o occorrido ao conhecimento de $\mathrm{V} . \mathrm{Ex}^{\mathrm{a}}$, a fim de providenciar a respeito, pois à passar impune um tal procedente, pode a insubordinação chegar a um ponto desastroso, visto a grande porção de Índios que existe naquelle Município. (Ofício de João Baptista D’Oliveira ao Presidente de Província Cel. Antonio Pedro D’Alencastro, Cuiabá 22 de Julho de 1861, p. 17) 
O documento não afirma que foram os capitães os responsáveis pela ação, até porque precisavam continuar a ser diplomáticos com as autoridades estabelecidas, como determinavam suas pautas culturais. No entanto, é bem possível que tenha sido uma ação deles. Para livrarem-se da acusação, deixaram o soldado sair da Aldeia para resgatar os índios recrutados para o trabalho externo ao aldeamento. É bem provável que essa tenha sido uma forma deles demonstrarem que não estavam de acordo com aquele tipo de convocatória, mesmo que, por esse trabalho, recebessem salários ou brindes. $\mathrm{O}$ fato é que as providências foram tomadas contra essa e outras insubordinações indígenas, de acordo com as correspondências entre as duas instâncias. Entretanto, as correções não foram silenciadas.

Em um dos ofícios de 1862, aparece uma denúncia publicada no Diário do Rio de Janeiro, do dia 8 de Março, sobre um bárbaro castigo contra vinte índios, entregues ao Quartel Militar da Villa de Miranda pelo respectivo Director de Aldeias. A repercussão da notícia, em cadeia nacional, fez com que o referido Diretor prestasse esclarecimentos ao Presidente da Província sobre o ocorrido. O acusado escusou-se, como era esperado, dissimulando o ocorrido. “[...] cumpreme scientificar á V. $\operatorname{Ex}^{\mathrm{a}}$ [...] que derão lugar a que se applicasse esse castigo, alias mui limitado, como uma correção aos referidos Índios, que se havião revoltado contra o Director" (Ofício do Director geral dos Índios, João Baptista D’Oliveira ao Presidente de Província Conselheiro Herculano Ferreira Penna. Cuiabá, 31 de Março de 1862, p. 22-23).

A Aldêa Normal de Miranda não teve o apoio financeiro e nem o tempo necessário para se organizar e progredir como desejavam os missionários, os regionais, as autoridades oficiais e os próprios Terena. Em 1864 eclodiram as primeiras batalhas da Guerra contra o Paraguai. Em 1860, o Director Geral dos Índios havia perdido a comunicação com o Diretor das Aldeias do Baixo Paraguay - Frei Mariano de Bagnaia. Em seu Relatório sobre o estado da Catechese e Civilização ao Vice-Presidente da Província, o Diretor Geral dos Índios informara a invasão da força paraguaia no Sul de Mato Grosso.

[...] Nada posso informar a V. Exa sobre o estado das Aldeas de N. Snr ${ }^{\mathrm{a}}$ do Bom conselho d'Albuquerque, e da Normal de Miranda; e bem assim da tentativa de aldeamento dos Índios Caiuás incumbidas ao Missionário Frei Ângelo de Caramanico, em conseqüência de achar-se aquella parte da Província occupada pelos Paraguayos desde janeiro do anno passado, não se sabendo ao menos o destino que tiverão não só aquelle Missionário, como Frei Mariano Bagnaia, quem dirigia a Aldea de Miranda (Relatório do 
As relações interétnicas: os Terena e os demais atores sociais em Mato Grosso do Sul Noêmia dos Santos Pereira Moura; Rosalvo Ivarra Ortiz

Estado da Catechese do Director Alexandre José Leite ao Vice Presidente da Província Cel. Albano de Souza Osório, Cuiabá, 22 de Junho de 1861. Localizado no II Livro Copiador das cartas expedidas pela Diretoria Geral dos Índios - Província de Mato grosso (1860-1873). Arquivo do Estado de mato Grosso em Cuiabá. Material Microfilmado: 64-65).

À época desse sucinto Relatório, Frei Mariano tinha sido aprisionado pelos combatentes paraguaios e os aldeamentos normais e regulares haviam sido despovoados. Só após o restabelecimento da paz é que os indígenas saíram de seus esconderijos para retornarem às suas aldeias. Nas Aldeias reconhecidas pelas autoridades oficiais, como já mencionamos anteriormente, os indígenas enfrentaram poucos problemas, além da total devastação causada pelos invasores. O mesmo não ocorreu em relação às aldeias espontâneas. Essas se encontravam destruídas e ocupadas por fazendeiros recentemente estabelecidos em terras devolutas tidas como espaços vazios. O Estado, acionado pelos Terena, pôs-se a legislar em favor de quem estava amparado pela Lei Imperial - a Lei de Terras. Com isso, queremos concluir que somente os Terena da Aldêa Regular de Miranda encontravam-se amparados pelo Imperador. Acerca desses índios tratava o Diretor Geral de Índios, no trecho abaixo destacado do Relatório de 1869.

Tendo sido informado que os Índios d'Aldea Normal da Villa de Miranda, que achavão-se dispersos em consequiência da mesma invasão, regressarão da mesma Villa, tratei logo de propor Capitão Caetano da Silva Albuquerque para Director Interino da mesma aldea, cuja proposta foi approvada pelo Exmo Governo Provincial.

Consta-me que esses Índios continuão a abastecer de gêneros alimentícios aos moradores do lugar [...] (Ofício do Director Geral dos Índios Alexandre José Leite ao Presidente de Província Gen. Barão de Melgaço, Cuiabá, 27 de Julho de 1869, p. 71-73).

Aos Terena submetidos às leis imperiais dava-se proteção, os demais ficavam à própria sorte a procurar emprego nas fazendas. Essa correspondência, acima destacada, nos leva a refletir sobre a situação na qual ficaram os Terena e os demais grupos Guaná quando regressaram à Villa de Miranda. Com a grande maioria de suas aldeias ocupadas, é provável que tenham procurado alojamento no aldeamento Normal de Miranda, nas fazendas circunvizinhas ou ainda, nos ermos desocupados. O fato é que a partir de 1869 voltam a aparecer no Livro Copiador de Correspondências da Diretoria Geral dos Índios (1860-1873) reivindicando os territórios nos quais tinham desenvolvido sua territorialidade, antes da referida Guerra. Todavia, as expedições à Capital da Província são relatadas a partir de 1871 . 
As relações interétnicas: os Terena e os demais atores sociais em Mato Grosso do Sul

Noêmia dos Santos Pereira Moura; Rosalvo Ivarra Ortiz

Naquelas viagens as lideranças Terena buscavam chamar a atenção das autoridades para seus problemas e eram recebidas com honras de Estado, do qual receberam brindes (ferramentas, roupas, quinquilharias), alimentação e reembolso referentes às despesas de viagem. Os Capitães Terena, reconhecidos pelas autoridades governamentais, denunciavam a invasão de suas terras e solicitavam a intervenção estatal. Percebe-se que os líderes Terena conheciam os códigos da legalidade e as instâncias constituídas. Assim os apresenta o Director de Índios Antonio Luiz Brandão (1871):

Acerca do Índio da tribu Terena, de nome José Caetano, de quem trata o officio de V. $\operatorname{Ex}^{\mathrm{a}}$ de 7 do corrente, cujo recebimento tenho a honra de accusar, o que sei e posso afirmar a V. $\mathrm{Ex}^{\mathrm{a}}$ é que o dito índio com mais alguns de sua tribu, em numero de 17 , procurou-me para representar que era filho do fallecido Pedro Tavares, Capitão da aldeã do ipégue, no districto de Miranda, e seo substituto, que por occasião da invasão paraguaya não só a sua tribu, como todas as outras, e mais habitantes do districto abandonarão os seos lares e retirarão-se para os montes e bosques, onde permanecerão por 6 annos; que ultimamente, voltando os moradores reocuparem os seos domicílios, elles Terenas encontrarão sua aldeã Ipegue occupada por Simplicio Tavares, por autonomasia Piche (sic), o qual lhes obsta a repovoarem e lavrarem suas antigas terras e seos antepassados; pelo que vinhão pedir providencias para não serem esbulhados de suas propriedades das quaes não podião desprender-se. Um outro Índio da mesma tribu de nome Victorino, que farda-se como alferes, e pertence á aldeã do Nachedache, distante da Ipegue uma légoa, fez-me igual reclamação.

V. Ex ${ }^{a}$ conhece o estado de aniquilação completa a que forão reduzidos a Villa e todos districtos de Miranda; que o director dos Índios daquellas aldêas, Frei Mariano de Baguaia foi prisioneiro dos paraguayos até quase o fim da guerra, e que hoje é Vigário de Corumbá, onde reside, não podendo por isso tomar promptas providencias a favor daquelles índios, e nem informar a esta Directoria acerca de occorencias que se dão naquellas aldêas.

Agora, porem, que existe no logar de Miranda um corpo de tropas, e que por alli vão affluindo os antigos moradores que escaparão da devastação, pareceme conveniente que $\mathrm{V}$. $\mathrm{Ex}^{\mathrm{a}}$ recomende ao commandante militar e ás autoridades do local toda proteção a favor dos índios, e que os mantenha em suas terras, visto como serão precisos ainda annos para que Miranda volte ao seo antigo estado, e tenha as autoridades próprias de uma villa.

Se não houver grande repugnancia da parte dos Índios, convirá reunil-os em uma só aldêa, no que haverá grande proveito para elles e para a sociedade, e isto póde V. Exa recommendar ao Commandante militar (Ofício do Director Geral dos Índios Antonio Luiz Brandão ao Presidente da Província Tem. Cel. Dr. Francisco José Cardoso Junior, Cuiabá, 9 de Novembro de 1871, p. 79-80). 
Foram acatados os reclames dos Capitães, embora eles não aceitassem a proposta de um único aldeamento. Essa formação era incompatível com as anteriores baseadas nos troncos linguísticos. Para o Estado era conveniente que os grupos Guaná permanecessem na região de Miranda, cuja mão-de-obra era fundamental para o soerguimento da cidade, que fora amplamente destruída pelos paraguaios. Os Terena se tornaram imprescindíveis, naquele contexto, enquanto mão-de-obra e fornecedores de gêneros alimentícios e artefatos; exerciam diversas funções, além de dominarem a língua portuguesa e respeitarem as autoridades constituídas, desde que fossem por elas também reconhecidos.

$\mathrm{Na}$ verdade, a fixação promovida pelo Estado Brasileiro em nada contrariava a filosofia política da Directoria Geral dos Índios que era aproximar os índios amigos das povoações, para que os convívios com os civilizados pudessem "adoçar os costumes selvagens". Abrandados em sua selvageria pelas letras, exemplos, artes, ofícios e pelo ensino religioso os braços indígenas ficariam à disposição do País. Contudo, coube ao Império a tarefa de agradá-los satisfazendo algumas de suas exigências e negociando outras. O propósito de reaproximação foi atingido e as negociações das terras estenderam-se até o século XX. Em 1905, foram demarcadas as Reservas Federais Indígenas Terena Ipegue e Cachoeirinha, antes mesmo da criação do SPI (AZANHA, 2004).

Apesar dos objetivos traçados pelos órgãos institucionais e institucionalizadores, as reservas exerceram um duplo papel. Ao mesmo tempo em que concretizavam a filosofia da Diretoria Geral dos Índios, implementada pelo Serviço de Proteção aos Índios (SPI), constituiu-se no lócus de fortalecimento da identidade étnica Terena. Para o Governo, em transição do Império para a República, fixar populações indígenas em pontos próximos às povoações e em constante contato com o homem civilizado levaria os índios a adoçar os costumes selvagens e desconstruir preconceitos. Além de aumentar numericamente a população cujos braços seriam muito úteis ao País (Diretoria Geral dos Índios, 1871: 75-76).

Para os Terena significava o reagrupamento tribal e a oportunidade de reconstituição do modus vivendi indígena. Os Terena, que aos olhos dos brasileiros estavam integrados à sociedade nacional, percebiam que para preservar seus direitos indígenas fazia-se necessário preservar traços de sua indianidade. Enquanto a meta do governo era acelerar a assimilação, a dos indígenas era preservar suas terras e seus direitos. Ao passo que a etnia reorganizava seu modus vivendi, o Estado se encarregava de modernizar-se. A atenção estatal desviava-se dos indígenas vistos como acomodados à situação nacional e voltava-se para os ditos arredios e 
As relações interétnicas: os Terena e os demais atores sociais em Mato Grosso do Sul

Noêmia dos Santos Pereira Moura; Rosalvo Ivarra Ortiz

selvagens. Essa foi uma das causas pelas quais os Terena saíram da Agenda nacional e consequentemente da História. Sua situação, do ponto de vista das autoridades brasileiras, estava encaminhada. A completa inserção e assimilação da etnia era uma questão de tempo. Paulatinamente, seriam absorvidos como trabalhadores nacionais, miscigenados e abrasileirados. Destacamos abaixo uma fala que resumiu a fase de adesão final dos indígenas à civilização.

Nas fases anteriores atraímos e habituamos os indígenas a alguns usos da civilização, restando-nos, no entanto, ainda mostrar-lhes como se adquirem ou conseguem o necessário para os hábitos que contraíram dando-lhes os ensinamentos do trabalho que representa o esforço despendido ou o capital necessário à sua manutenção. Para esse fim só dispomos de um meio persuasivo que é o exemplo do civilizado: compõe-se de turmas mistas nas quais o elemento indígena predomine pelo número e paga-se-lhes um salário equivalente ao seu trabalho, paga que para não se sobrecarregar os cofres públicos represente conjuntamente com a alimentação distribuída pela cozinha geral e a vestimenta - o valor de uma diária paga ao trabalhador rural civilizado; feitos os pagamentos semanalmente para melhor instigá-los, mantendo-se aberto o armazém que possuirá o estabelecimento para fornecer aos índios em troca de seus salários e conforme seus desejos coisas que não sejam de uso comum. Inútil acrescentar que se manterá uma rigorosa fiscalização e escrituração desse armazém, porquanto o índio desconhecedor no princípio completamente do valor monetário, dará todo o seu salário por um objeto que deseje muito inferior, ou desejará adquirir mundos e fundos com a pequena paga dos trabalhos que receber [...] (LIMA, 1995, p. 183184 , grifos do autor).

Civilizar, na ótica governamental, era transformar os indígenas em trabalhadores nacionais com todas as necessidades e desejos de consumir e pagar os bens produzidos. É nesse cenário, traçado pelo estrategista governo positivista brasileiro, que as populações indígenas irão, na primeira metade do século XX, desconstruir a tese da assimilação irreversível. Focaremos especificamente o caso de territorialização dos Terena.

Demarcadas as Reservas de Ipegue e Cachoeirinha em 1905, essa etnia vai moldar, nos anos seguintes, uma nova organização social, política econômica e cultural, sob os auspícios do órgão gestor da política indigenista - o Serviço de Proteção aos Índios e Localização de Trabalhadores Nacionais - SPILTN. Sendo reconhecidos como integrados à estrutura socioeconômica da região, coube aos Terena estabelecer as características que demarcassem a diferença entre eles e a sociedade nacional. Em a Sociologia do Brasil Indígena (1972), Roberto Cardoso de Oliveira analisa qual tipo de assistência foi oferecido pelo SPI aos civilizados. A proteção, segundo Cardoso de Oliveira, se restringe à terra e à 
ação policial. Mesmo assim, os Terena preocuparam-se constantemente em procurar a proteção do Posto Indígena e "evidenciar sua condição de índio diante da comunidade indígena e, particularmente, frente ao órgão protetor" (OLIVEIRA, 1976, p. 21).

A garantia da terra, na qual podiam viver e plantar sem a intermediação do patrão, com a proteção do governo brasileiro contra os fazendeiros usurpadores foi fundamental naquele momento, para os índios. Ser reconhecido enquanto Índio era o pré-requisito para assegurar as terras. Os Terena perceberam a importância do fortalecimento de uma identidade específica enquanto tais pelo governo e pelos demais povos indígenas. O povo Terena em contato há séculos com várias situações de superioridade bélica e política, percebeu o contexto no qual estava vivendo e explorou ao seu modo a nova política indigenista protecionista.

Cardoso de Oliveira (1976) destacou uma tese sobre o ambíguo papel dos Postos Indígenas no processo de assimilação.

[...] embora possa ser identificada claramente sua ação como contraassimiladora ou de resistência ao processo de assimilação, não se pode deixar de apontar a ação protetora desses Postos, mormente aquela que se refere à defesa das Terras Indígenas, como uma condição básica para a sobrevivência física dos grupos tribais, pois sem ela muitas tribos já estariam dizimadas (OLIVEIRA, 1976, p. 21-22).

No processo de reconstrução da vida em comunidade, havia um conflito entre o SPI e os Terena crentes. Os Terena crentes entrevistados ressaltaram que poucas atenções recebiam do SPI. A atenção protetora, provavelmente, estava voltada às populações indígenas que desafiavam o poderio do Estado. Como vimos anteriormente, a assistência aos Terena se concretizava na posse da reserva e na ação policial do Posto Indígena. Os Postos eram subvencionados pelo órgão tutor e dirigidos por um funcionário do Serviço. Esse funcionário estava submetido às ordens da Inspetoria do SPI35. Outras assistências - educacional, médica e alimentícia - estavam previstas no programa do Serviço, embora a verba para essa rubrica fosse insuficiente. Segundo suas reivindicações ao Estado e aos missionários protestantes no início do século XX, aos Terena interessava ter escolas para educar os seus filhos. Entretanto, a atenção orçamentária do SPI estava voltada para os índios não integrados à sociedade nacional.

Em busca de suprir essas necessidades, novas relações sociais foram construídas. As relações interétnicas tornaram-se, dessa forma, muito mais abrangentes, o que era objetivado 
pelo SPI. Muitos dos indígenas originários de fazendas destinavam-se a continuar trabalhando nas fazendas circunvizinhas à área indígena, porém morando na Reserva, para assegurar seu espaço. A comercialização de gêneros alimentícios e artesanais continuava a ser realizada nos distritos e cidades próximas às aldeias indígenas. Os Terena se ajustavam para realizar trabalhos temporários para os regionais. A mobilidade entre aldeias e cidades aumentara com a proximidade estabelecida. Ampliavam-se as possibilidades de integração do Terena à sociedade brasileira, segundo pensavam as autoridades civis. Essa experiência Terena foi amplamente divulgada pelo Governo republicano na primeira metade do século XX e durante todo o período da ditadura militar.

\section{CONSIDERAÇÕES FINAIS}

Para finalizarmos voltamos nosso olhar para as relações dos Terena com os demais agentes sociais que viviam e influenciavam politicamente o sul de Mato Grosso e para o fortalecimento do movimento indígena que vai compor-se em Mato Grosso do Sul. Dessa forma, demonstramos que essa etnia foi uma das protagonistas na constituição e consolidação dos Estados do Mato Grosso e Mato Grosso do Sul na Região Centro-Oeste brasileira. Lutou por seus territórios contra os paraguaios e depois contra os brasileiros, que ao finalizar a Guerra do Paraguai (1864-1870) se apossaram das terras de suas aldeias. Fortaleceram-se enquanto etnia e receberam novos territórios nos quais produziram e reproduziram o modus vivendi Terena/Aruak. Todavia, novas relações, novos costumes e comportamentos, bem como novas religiosidades foram sendo aceitas pelos Terena contemporâneos e, portanto, ressignificando a sua cosmologia.

Ainda novas experiências políticas fortaleceram as lideranças religiosas e civis para reivindicar novos espaços sócio-políticos como a Administração Executiva Regional da FUNAI de Campo Grande, as chefias de Postos Indígenas nas Terras Indígenas, as funções de agente de saúde, professor, zelador, vigia, entre outras nas aldeias e fora destas e, principalmente as de pastor das Igrejas Evangélicas e dirigente da Igreja Católica nas aldeias e em seus arredores (cidades ou distritos). Os Terena aos poucos foram interagindo com a sociedade brasileira e ocupando novos espaços de poder. O mais interessante, entretanto, foi perceber como esses novos comportamentos, valores e espaços de poder repercutiram nas relações sócio-político-religiosas no âmbito das Aldeias Bananal e Ipegue. Tal como na 
sociedade brasileira, verificamos que o movimento das identidades e questões religiosas cresceu em direção ao centro da vida social, política e econômica, tanto em escala quanto em importância também nas Aldeias Bananal e Ipegue.

\section{FONTES ARROLADAS}

Relatório de Joaquim Alves Ferreira, Director Geral dos Índios, Cuiabá, 2 de dezembro de 1848, 16 folhas. Localiza-se no Livro Copiador das Cartas expedidas pela diretoria Geral dos Índios - Província de Mato Grosso (1848-1860). Faltam as quatro primeiras páginas deste documento. Arquivo Público do Estado de Mato Grosso. (Material microfilmado).

Relato de Henrique José Vieira, Director Geral dos Índios a augusto Leverger, Presidente da Província de Mato grosso. Cuiabá, 28 de Dezembro de 1852 (p. 17- 18). Localiza-se no Livro Copiador das Cartas expedidas pela diretoria Geral dos Índios - Província de Mato Grosso (1848-1860). Arquivo Público do estado de Mato Grosso. (Material microfilmado).

Relatório de João Baptista D’Oliveira, Director Geral dos Índios, ao Presidente de Província Raimundo Lamare. Cuiabá, 31 de Dezembro de 1858. (p. 92-99). Localiza-se no Livro Copiador das Cartas expedidas pela diretoria Geral dos Índios - Província de Mato Grosso (1848-1860). Arquivo Público do Estado de Mato Grosso. (Material microfilmado).

Ofício do Director Geral dos Índios Antonio Luiz Brandão ao Presidente da Província Tem. Cel. Dr. Francisco José Cardoso Junior, Cuiabá, 9 de Novembro de 1871. Localizado no II Livro Copiador das cartas expedidas pela Diretoria Geral dos Índios - Província de Mato grosso (1860-1873). Arquivo do Estado de Mato Grosso em Cuiabá. (Material Microfilmado).

Ofício de João Baptista D’Oliveira ao Presidente de Província Cel. Antonio Pedro D’Alencastro, Cuiabá 22 de Julho de 1861. Localizado no II Livro Copiador das cartas expedidas pela Diretoria Geral dos Índios - Província de Mato grosso (1860-1873). Arquivo do Estado de mato Grosso em Cuiabá. (Material Microfilmado).

Ofício do Director Geral dos Índios Alexandre José Leite ao Presidente de Província Gen. Barão de Melgaço, Cuiabá, 27 de Julho de 1869. Localizado no II Livro Copiador das cartas expedidas pela Diretoria Geral dos Índios - Província de 292 Mato grosso (1860-1873). Arquivo do Estado de Mato Grosso em Cuiabá. (Material Microfilmado).

\section{REFERÊNCIAS BIBLIOGRÁFICAS}

AÇÇOLINI, Graziele (2004). Protestantismo à moda Terena. Araraquara, SP: Tese de Doutorado em Ciências Sociais, 2004.

AZANHA, Gilberto. As Terras Indígenas Terena no Mato Grosso do Sul. In: www.trabalhoindigenista.org.br, 2004. 
CARVALHO, Fernanda. Koixomuneti e outros curadores: Xamanismo e práticas de cura entre os Terena. São Paulo: USP, Dissertação de Mestrado em Antropologia Social, 1996.

COSTA, Maria de Fátima. História de um País Inexistente: O Pantanal entre os séculos XVI e XVIII. São Paulo, Estação Liberdade: Kosmos, 1999.

LEITE, Eudes Fernando. Marchas na história: comitivas e peões-boiadeiros no Pantanal. Brasília: Ministério da Integração Nacional: Campo Grande, MS: Ed. UFMS, 2003.

LIMA, Antonio Carlos de Souza. Um Grande Cerco de Paz: Poder tutelar, indianidade e formação do Estado no Brasil. Rio de Janeiro: Vozes, 1995.

MOURA, Noêmia dos Santos Pereira. UNIEDAS: O Símbolo da Apropriação do Protestantismo Norte-Americano pelos Terena Crentes (1972-1993). Dissertação de Mestrado em História. UFMS, Campus de Dourados-MS, 2001.

MUSSI, Vanderléia Paes Leite. A Dinâmica da Organização social dos Terena, da Aldeia ao Espaço Urbano de Campo Grande - MS. São Leopoldo, RS, Dissertação de Mestrado em História, 2000.

OLIVEIRA, Roberto Cardoso de. Urbanização e Tribalismo: a integração dos índios Terena numa sociedade de classes. Rio de Janeiro: Zahar, 1968.

OLIVEIRA, Roberto Cardoso de. Do Índio ao Bugre: O Processo de Assimilação dos Terena. Rio de Janeiro: Francisco Alves, 1976.

OLIVEIRA, Roberto Cardoso de. A sociologia do Brasil indígena. Rio de Janeiro: Tempo Brasileiro, São Paulo: EDUSP, 1972.

SANT'ANA, Graziella Reis de. A Dinâmica do associativismo Terena no espaço Urbano. Marília, SP, Dissertação de Mestrado em Ciências Sociais, 2004.

SCHUCH, Maria Eunice Jardim. Xaray e Chané: Índios frente à expansão espanhola e portuguesa no Alto Paraguai. São Leopoldo, RS: UNISINOS, Dissertação de Mestrado em História. 1995.

SILVA, Verone Cristina. Missão, Aldeamento e Cidade: Os Guaná entre Albuquerque e Cuiabá (1819-1901). Cuiabá, MT: UFMT, Dissertação de Mestrado em História, 2001.

VARGAS, Vera Lúcia Ferreira. A construção do território Terena (1870- 1966): Uma sociedade entre a imposição e a opção. Universidade Federal do Mato Grosso do Sul, Dissertação de Mestrado, 2003.

VASCONCELOS, Cláudio Alves de. A Questão Indígena na Província de Mato Grosso: Conflito, trama e continuidade. Campo Grande, MS: Editora UFMS, 1999. 
As relações interétnicas: os Terena e os demais atores sociais em Mato Grosso do Sul

Noêmia dos Santos Pereira Moura; Rosalvo Ivarra Ortiz

VIVEIROS DE CASTRO, Eduardo. A Inconstância da Alma Selvagem e outros ensaios de Antropologia. São Paulo: Cosac \& Naify, 2002.

Recebido em: 12/12/2017 Aprovado em: 08/05/2018 